$2 \cdot 929(4)$ and $2 \cdot 852(6) \AA, \mathrm{O}(8) \cdots \mathrm{C}(20) 2 \cdot 865(7)$ and $3 \cdot 137$ (5) $\AA$ in molecules $A$ and $B$, respectively. They are observed despite the non-coplanarity of $N(19)$, $\mathrm{N}(6), \mathrm{C}(9)$ and $\mathrm{C}(10)$ with the imidazole plane.

In the molecular packing, which is presented in Fig. 2, no significant short contacts are observed.

The authors thank Dr S. Sobiak for providing the compound. This research was partly supported by the Polish Ministry of Education project No. RP.II.10.

\section{References}

Borowiak, T., Wolska, I., Baryla, M. \& SobiaK, S. (1989). Acta Cryst. C45, 448-451.

Di Rienzo, F., Domenicano, A. \& Riva di Sanseverino, L. (1980). Acta Cryst. B36, 586-591.

Domenicano, A., Vaciago, A. \& Coulson, C. A. (1975). Acta Cryst. B31, 221-234.
Epstein, J., Ruble, J. R. \& Craven, B. M. (1982). Acta Cryst. B38, $140-149$.

FukuYo, M., Hirotsu, K. \& HiguchI, T. (1982). Acta Cryst. B38, 640-643.

JASKóLSKI, M. (1982). Fourth Symp. Org. Cryst. Chem., Poznan, Poland, edited by Z. KaluSKI, pp. 70-71.

JOHNSON, C. K. (1976). ORTEPII. Report ORNL-5138. Oak Ridge National Laboratory, Tennessee, USA

Lehmann, M. S. \& LaRsen, F. K. (1974). Acta Cryst. A30, 580-584.

Main, P., Fiske, S. J., Hull, S. E., Lessinger, L., Germain, G., DeClerCQ, J.-P. \& WOOLFSON, M. M. (1980). MULTAN80. A System of Computer Programs for the Automatic Solution of Crystal Structures from X-ray Diffraction Data. Univs. of York, England, and Louvain, Belgium.

Motherwell, W. D. S. \& ClegG, W. (1978). PLUTO78. Program for plotting molecular and crystal structures. Univ. of Cambridge, England.

NARDELli, M. (1983). Comput. Chem. 7, 95-98.

Pople, J. A. \& Segal, G. A. (1966). J. Chem. Phys. 44, 32893296.

SHELDRICK, G. M. (1976). Program for crystal structure determination. Univ. of Cambridge, England.

Acta Cryst. (1991). C47, 1922-1925

\title{
Structure of a 4-Phenylcoumarin Derivative
}

\author{
By Kalyan Das and U. C. Sinha* \\ Department of Physics, Indian Institute of Technology, Bombay 400 076, India \\ D. D. NARKHEDE AND P. R. IYER \\ Department of Chemistry, Indian Institute of Technology, Bombay 400 076, India
}

AND R. BOHRA

Department of Chemistry, University of Rajasthan, Jaipur 302016, India

(Received 6 December 1990; accepted 13 February 1991)

\begin{abstract}
Hydroxy-6,7-trans-dimethyl-4-phenyl6,7-dihydro- $2 H, 8 H$-benzo[1,2-b:3,4- $\left.b^{\prime}\right]$ dipyran-2,8dione, $\mathrm{C}_{20} \mathrm{H}_{16} \mathrm{O}_{5}$, m.p. $=512-513 \mathrm{~K}, M_{r}=336 \cdot 34$, triclinic, $P \overline{1}, \quad a=8.414(3), \quad b=9.929$ (4), $\quad c=$ 10.358 (2) $\AA, \quad \alpha=96.77$ (3), $\quad \beta=105.08$ (2), $\quad \gamma=$ $99.47(3)^{\circ}, \quad V=812.39 \AA^{3}, \quad Z=2, \quad D_{x}=$ $1.363 \mathrm{Mg} \mathrm{m}^{-3}, \quad \lambda($ Mo $K \alpha)=0.71069 \AA, \quad \mu($ Mo $K \alpha)$ $=0.059 \mathrm{~mm}^{-1}, F(000)=352, T=295 \mathrm{~K}$, final $R=$ $0.062, w R=0.072$, for 2133 observed reflections. The crystal contains two isomers in approximately 60:40 proportions. Atoms $\mathrm{C}(6), \mathrm{C}(7)$ and their attached $\mathrm{H}$ atoms occupy alternative positions in the two isomers. $\mathrm{H}(6) / \mathrm{H}\left(6^{\prime}\right)$ and $\mathrm{H}(7) / \mathrm{H}\left(7^{\prime}\right)$ are trans to each other.
\end{abstract}

\footnotetext{
* To whom correspondence should be addressed.
}

Introduction. In the past 30 years or so, several naturally occurring coumarins have been isolated from higher plants like, Umbelliferae, Rutaceae, Guttiferae, Rubiaceae, Leguminosae and also from various micro-organisms (Murray, Mendez \& Brown, 1982). Many coumarins bearing a phenyl group at the 4-position have an isoprenoid $\left(\mathrm{C}_{5}\right)$ unit in the form of a six-membered pyran structure such as the 2,3-dimethyl-2H-1-pyran-4-one unit (Dewick, 1982). In the process of synthesizing a naturally occurring 4-phenylcoumarin derivative, the title compound was obtained. In order to study the orientations of the methyl groups and the $\mathrm{H}$ atoms, attached to the asymmetric centres $[\mathrm{C}(6)$ and $\mathrm{C}(7)]$, and the conformation of the chromanone ring (see below), the crystal structure of the above compound

(C) 1991 International Union of Crystallography 
was analyzed using $\mathrm{X}$-ray diffraction techniques. The ${ }^{1} \mathrm{H}$ NMR spectrum showed up-field shifts for the $\mathrm{C}(6)$ proton and the methyl attached to it.

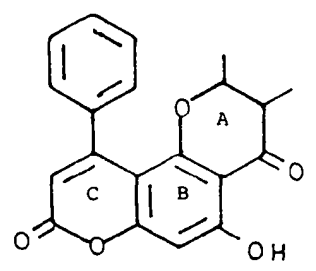

Experimental. The reaction of phloroglucinol and tiglic acid gave 5,3-dihydroxy-trans-2,3-dimethylchromanone, which on Pachmann condensation with ethyl benzoylacetate gave the title compound (Narkhede, 1990). The colourless crystals were obtained from benzene solution.

X-ray intensity data from a crystal, dimensions $0.30 \times 0.22 \times 0.30 \mathrm{~mm}$, were collected using an Enraf-Nonius CAD-4 diffractometer with graphitemonochromated Mo $K \alpha(\lambda=0.71069 \AA)$ radiation. The cell constants were refined using 25 reflections in the range $6 \leq \theta \leq 11^{\circ}$. Two standard reflections ( $\overline{1} 2 \overline{4}$, $\overline{1} \overline{3}$ ), checked every $1800 \mathrm{~s}$, showed no significant variation in intensity. A total of 2140 unique reflections were scanned, $\omega / 2 \theta$ mode, in the range 2 $\leq \theta \leq 25^{\circ} ; \theta \leq h \leq 0,-11 \leq k \leq 11,-12 \leq l \leq 12$. Data were corrected for Lp factors, neglecting the effect of absorption and extinction. The structure solution was attempted with default settings for MULTAN11/84 (Main, Germain \& Woolfson, 1984) for which the phase set with the best CFOM revealed four fused rings, but assignment of the proper positions of the atoms was ambiguous. The structure was solved by MULTAN88 (Debaerdemaeker, Germain, Main, Refaat, Tate \& Woolfson, 1988) with a selected weight for the zero quartet, CFOM $=2.442$ and $\operatorname{RESID}=15 \cdot 72$. During the initial refinement, the atoms $\mathrm{C}(6)$ and $\mathrm{C}(7)$ showed high thermal parameters and one high peak appeared near each of them. This problem was resolved by assigning two positions for each with s.o.f.'s of 0.6 and 0.4 , for both $\mathrm{C}(6)$ and $\mathrm{C}(7)$. Non-H atoms were refined with anisotropic thermal parameters. All $\mathrm{H}$ atoms, including those with s.o.f.'s 0.6 and 0.4 , were located from a difference Fourier map and refined isotropically. The structure refinement was by the least-squares method based on $F$ values, using SHELX76 (Sheldrick, 1976). The atomic scattering factors for all the atoms were taken from SHELX76. In the final refinement, 316 parameters were refined using 2133 observed reflections. Final $R=0.0619$ and $w R=$ 0.0721 \{where $w=1.000 /\left[\sigma^{2}(F)+g\left(F^{2}\right)\right]$ with $g=$ $0.00002\},(\Delta / \sigma)_{\max }=0 \cdot 163$. In the final difference $\operatorname{map}(\Delta \rho)_{\max }=0.270$ and $(\Delta \rho)_{\min }=-0.220 \mathrm{e}^{-3}$. A CYBER-180 was used for all computations.

Table 1. Atomic coordinates $\left(\times 10^{4}\right)$ and equivalent temperature factors $U_{\mathrm{eq}}\left(\AA^{2} \times 10^{3}\right)$ for non- $\mathrm{H}$ atoms with e.s.d.'s in parentheses

$$
U_{\mathrm{cq}}=\sum_{i} \sum_{j} U_{i j} a_{i}^{*} a_{j}^{*}\left(\mathbf{a}_{i} \cdot \mathbf{a}_{j}\right) \text {. }
$$

$\begin{array}{lcccc} & x & y & z & U_{\text {eq }} \\ \mathrm{O}(1) & 8359(2) & 3050(2) & 7108(2) & 56(1) \\ \mathrm{C}(2) & 8487(3) & 3634(3) & 5981(3) & 56(2) \\ \mathrm{C}(3) & 8181(3) & 5023(3) & 5987(3) & 56(2) \\ \mathrm{C}(4) & 7812(3) & 5736(2) & 7019(2) & 46(1) \\ \mathrm{C}(4 a) & 7787(3) & 5109(2) & 8219(2) & 44(1) \\ \mathrm{C}(4 \mathrm{~b}) & 7591(3) & 5762(2) & 9435(2) & 45(1) \\ \mathrm{O}(5) & 7475(2) & 7099(2) & 9521(2) & 59(1) \\ \mathrm{C}(6) \dagger & 7624(5) & 7862(4) & 10838(4) & 58(2) \\ \mathrm{C}\left(6^{\prime}\right) \ddagger & 6871(6) & 7750(6) & 10498(6) & 58(2) \\ \mathrm{C}(7) \dagger & 6725(5) & 7103(4) & 11680(4) & 59(2) \\ \mathrm{C}\left(7^{\prime}\right) \ddagger & 7640(7) & 7411(6) & 11890(5) & 58(2) \\ \mathrm{C}(8) & 7298(3) & 5754(3) & 11745(3) & 59(2) \\ \mathrm{C}(8 \mathrm{a}) & 7566(3) & 5064(2) & 10538(2) & 45(1) \\ \mathrm{C}(9) & 7787(3) & 3668(2) & 10418(2) & 50(2) \\ \mathrm{C}(10) & 8037(3) & 3027(2) & 9263(3) & 52(2) \\ \mathrm{C}(10 \mathrm{a}) & 8050(3) & 3757(2) & 8212(2) & 46(1) \\ \mathrm{O}(11) & 8793(3) & 2920(2) & 5103(2) & 76(2) \\ \mathrm{C}(12) & 7176(4) & 9243(3) & 10519(3) & 84(2) \\ \mathrm{C}(13) & 6900(4) & 7922(4) & 13022(3) & 87(2) \\ \mathrm{O}(14) & 7282(3) & 5180(2) & 12731(2) & 78(2) \\ \mathrm{O}(15) & 7772(3) & 2965(2) & 11441(2) & 69(1) \\ \mathrm{C}(41) & 7394(3) & 7120(2) & 6860(2) & 47(2) \\ \mathrm{C}(42) & 8601(3) & 8224(3) & 6782(3) & 57(2) \\ \mathrm{C}(43) & 8171(3) & 9475(3) & 6584(3) & 66(2) \\ \mathrm{C}(44) & 6560(3) & 9655(3) & 6439(3) & 66(2) \\ \mathrm{C}(45) & 5337(3) & 8562(3) & 6484(3) & 66(2) \\ \mathrm{C}(46) & 5760(3) & 7303(3) & 6697(3) & 59(2) \\ & & & & \end{array}$

+ Site occupation factor 0.6 .

$\$$ Site occupation factor $0 \cdot 4$.

Table 2. Bond distances $(\AA)$ and angles $\left({ }^{\circ}\right)$ with e.s.d.'s in parentheses

$\begin{array}{llll}C(2)-O(1) & 1.384(3) & C(12)-C\left(6^{\prime}\right) & 1.459(7) \\ C(10 a)-O(1) & 1.376(3) & C\left(7^{\prime}\right)-C\left(6^{\prime}\right) & 1.520(8) \\ C(3)-C(2) & 1.443(3) & C(8)-C(7) & 1.499(5) \\ O(11)-C(2) & 1.194(3) & C(13)-C(7) & 1.485(5) \\ C(4)-C(3) & 1.344(3) & C(8)-C\left(7^{\prime}\right) & 1.604(6) \\ C(4 a)-C(4) & 1.457(3) & C(13)-C\left(7^{\prime}\right) & 1.538(7) \\ C(41)-C(4) & 1.491(3) & C(8 a)-C(8) & 1.442(4) \\ C(4 b)-C(4 a) & 1.409(3) & O(14)-C(8) & 1.229(3) \\ C(10 a)-C(4 a) & 1.396(3) & C(9)-C(8 a) & 1.424(3) \\ O(5)-C(4 b) & 1.341(3) & C(10)-C(9) & 1.370(3) \\ C(8 a)-C(4 b) & 1.407(3) & O(15)-C(9) & 1.337(3) \\ C(6)-O(5) & 1.445(4) & C(10 a)-C(10) & 1.379(3) \\ C\left(6^{\prime}\right)-O(5) & 1.386(6) & C(42)-C(41) & 1.391(3) \\ C(7)-C(6) & 1.487(6) & C(43)-C(42) & 1.373(4) \\ C(12)-C(6) & 1.531(5) & C(45)-C(44) & 1.381(4) \\ C(44)-C(43) & 1.368(4) & C(46)-C(41) & 1.386(3) \\ C(46)-C(45) & 1.381(4) & & \end{array}$

\begin{tabular}{|c|c|c|c|}
\hline$C(10 a)-O(1)-C(2)$ & $122 \cdot 9(2)$ & $C(46)-C(41)-C(4)$ & $120 \cdot 2(2)$ \\
\hline$C(3)-C(2)-O(1)$ & $116 \cdot 0(2)$ & $C(13)-C(7)-C(6)$ & $113.7(3)$ \\
\hline $\mathrm{O}(11)-\mathrm{C}(2)-\mathrm{O}(1)$ & $116 \cdot 4(2)$ & $C(46)-C(41)-C(42)$ & $118.7(2)$ \\
\hline$C(4)-C(3)-C(2)$ & $123 \cdot 2(2)$ & $C(13)-C(7)-C(8)$ & $114 \cdot 4(3)$ \\
\hline$C(4 a)-C(4)-C(3)$ & $118 \cdot 9(2)$ & $C(8 a)-C(8)-C\left(7^{\prime}\right)$ & $114.0(3)$ \\
\hline$C(41)-C(4)-C(3)$ & $118.0(2)$ & $O(14)-C(8)-C\left(7^{\prime}\right)$ & $121 \cdot 2(3)$ \\
\hline$C(41)-C(4)-C(4 a)$ & $123 \cdot 1(2)$ & $O(14)-C(8)-C(8 a)$ & $121.9(2)$ \\
\hline$C(4 b)-C(4 a)-C(4)$ & $126 \cdot 1(2)$ & $C(8)-C(8 a)-C(4 b)$ & $120.1(2)$ \\
\hline$C(10 a)-C(4 a)-C(4)$ & $118 \cdot 3(2)$ & $C(8)-C\left(7^{\prime}\right)-C\left(6^{\prime}\right)$ & $107 \cdot 1(4)$ \\
\hline$C(10 a)-C(4 a)-C(4 b)$ & $115 \cdot 6(2)$ & $C(9)-C(8 a)-C(4 b)$ & $118.4(2)$ \\
\hline$O(5)-C(4 b)-C(4 a)$ & $117.3(2)$ & $C(10)-C(9)-C(8 a)$ & $120 \cdot 7(2)$ \\
\hline$C(8 a)-C(4 b)-C(4 a)$ & $121.9(2)$ & $C(13)-C\left(7^{\prime}\right)-C\left(6^{\prime}\right)$ & $116.0(4)$ \\
\hline$C(8 a)-C(4 b)-O(5)$ & $120 \cdot 8(2)$ & $O(15)-C(9)-C(10)$ & $118.9(2)$ \\
\hline$C(6)-O(5)-C(4 b)$ & $118.0(2)$ & $C(13)-C\left(7^{\prime}\right)-C(8)$ & $105 \cdot 9(4)$ \\
\hline$C\left(6^{\prime}\right)-O(5)-C(4 b)$ & $122 \cdot 2(3)$ & $C(8 a)-C(8)-C(7)$ & $117.8(2)$ \\
\hline$C(7)-C(6)-O(5)$ & $115 \cdot 2(3)$ & $O(14)-C(8)-C(7)$ & $119 \cdot 4(3)$ \\
\hline$C(12)-C(6)-O(5)$ & $103.4(3)$ & $C(9)-C(8 a)-C(8)$ & $121.5(2)$ \\
\hline$C(12)-C(6)-C(7)$ & $117.8(3)$ & $O(15)-C(9)-C(8 d)$ & $120.4(2)$ \\
\hline$C(10 a)-C(10)-C(9)$ & $118 \cdot 6(2)$ & $C(46)-C(45)-C(44)$ & $119 \cdot 6(2)$ \\
\hline$C(4 a)-C(10 a)-O(1)$ & $120 \cdot 6(2)$ & $C(45)-C(44)-C(43)$ & $119.8(2)$ \\
\hline$C(10)-C(10 a)-O(1)$ & $114.7(2)$ & $C(44)-C(43)-C(42)$ & $121 \cdot 1(2)$ \\
\hline$C\left(7^{\prime}\right)-C\left(6^{\prime}\right)-O(5)$ & $1113(4)$ & $C(10)-C(10 a)-C(4 a)$ & $124.7(2)$ \\
\hline$C(12)-C\left(6^{\prime}\right)-O(5)$ & $110.4(4)$ & $C(42)-C(41)-C(4)$ & $121 \cdot 0(2)$ \\
\hline$C(12)-C\left(6^{\circ}\right)-C\left(7^{\prime}\right)$ & $111 \cdot 1(4)$ & $C(43)-C(42)-C(41)$ & $119.9(2)$ \\
\hline$C(8)-C(7)-C(6)$ & $106 \cdot 8(3)$ & $C(45)-C(46)-C(41)$ & $120 \cdot 9(2)$ \\
\hline
\end{tabular}


Discussion. The atomic coordinates for the non- $\mathrm{H}$ atoms are listed in Table 1 and the bond lengths and angles are in Table $2 .^{*}$ The crystal is a racemate. Figs. $1(a)$ and $1(b)$ (Motherwell \& Clegg, 1978), viewed along the same projection, show the two isomers in which the atoms at chiral centres, $C(6)$ and $C(7)$, and the $H$ atoms attached to them occupy alternative positions with occupancies 0.6 and 0.4 respectively. For both isomers, the methyls attached to $\mathrm{C}(6) / \mathrm{C}\left(6^{\prime}\right)$ and $\mathrm{C}(7) / \mathrm{C}\left(7^{\prime}\right)$ are trans to each other. The torsion angles are listed in Table 3 . The pyran ring $A$ has a distorted half-chair conformation compared to the favourable sofa conformation found for

* Lists of structure factors, anisotropic thermal parameters, $\mathrm{H}$-atom parameters and least-squares planes have been deposited with the British Library Document Supply Centre as Supplementary Publication No. SUP 53995 (15 pp.). Copies may be obtained through The Technical Editor, International Union of Crystallography, 5 Abbey Square, Chester CH1 2HU, England.

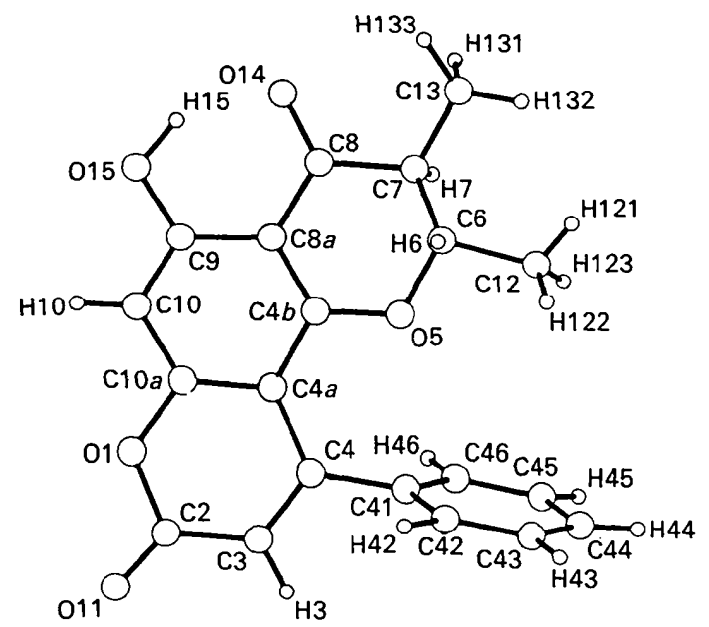

(a)

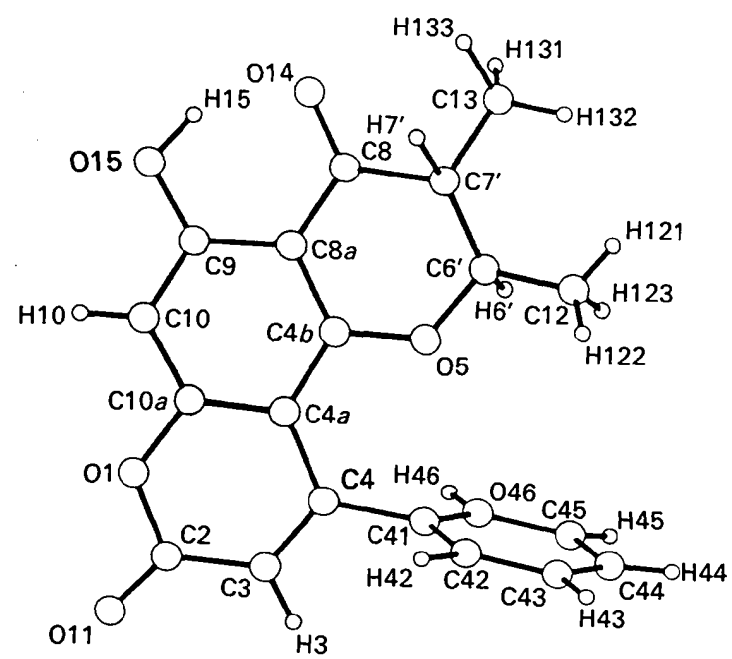

(b)

Fig. 1. General view of the isomers $(a) \mathrm{I}$ and $(b)$ II.
Table 3. Important torsion angles $\left(^{\circ}\right)$ with e.s.d.'s in parentheses

$$
\begin{array}{lc}
\mathrm{H}(6)-\mathrm{C}(6)-\mathrm{C}(7)-\mathrm{H}(7) & 171.5(9) \\
\mathrm{H}\left(6^{\prime}\right)-\mathrm{C}\left(6^{\prime}\right)-\mathrm{C}\left(7^{\prime}\right)-\mathrm{H}\left(7^{\prime}\right) & -177.0(13) \\
\mathrm{C}(12)-\mathrm{C}(6)-\mathrm{C}(7)-\mathrm{C}(13) & -56.9(5) \\
\mathrm{C}\left(12^{\prime}\right)-\mathrm{C}(6)-\mathrm{C}(7)-\mathrm{C}\left(13^{\prime}\right) & 64.5(6)
\end{array}
$$

Table 4. Important inter- and intramolecular distances $(\AA)$ and angles $\left(^{\circ}\right)$

\begin{tabular}{lcccl} 
& & & $\mathrm{C}-\mathrm{H} \cdots \mathrm{O} /$ & \multicolumn{1}{c}{ Symmetry } \\
& $\mathrm{O} \cdots \mathrm{O} / \mathrm{C} \cdots \mathrm{O}$ & $\mathrm{H} \cdots \mathrm{O}$ & $\mathrm{O}-\mathrm{H} \cdots \mathrm{O}$ & \multicolumn{1}{c}{ operations } \\
$\mathrm{O}(15)-\mathrm{H}(15) \cdots \mathrm{O}(14)$ & $2.585(2)$ & $1 \cdot 709(3)$ & $145 \cdot 6(4)$ & $x, y, z$ \\
$\mathrm{C}\left(7^{\prime}\right)-\mathrm{H}\left(7^{\prime}\right) \cdots \mathrm{O}(1)$ & $3.380(7)$ & $2 \cdot 516(12)$ & $135.0(9)$ & $2-x, 1-y, 2-z$ \\
$\mathrm{C}(3)-\mathrm{H}(3) \cdots \mathrm{O}(14)$ & $3.287(3)$ & $2 \cdot 447(10)$ & $148 \cdot 6(7)$ & $x, y,-1+z$ \\
$\mathrm{C}(44)-\mathrm{H}(44) \cdots \mathrm{O}(1)$ & $3.370(3)$ & $2 \cdot 684(10)$ & $131 \cdot 5(8)$ & $x, 1+y, z$
\end{tabular}

papuanic acid (Stout, Rickernell \& Sears, 1968). The atoms $C(6)$ and $C(7)$ are displaced by -0.307 (4) and $0.344(4)$ for molecule $I$ and $0.302(5)$ and -0.388 (6) $\AA$ for molecule II from the least-squares plane passing through the remaining four atoms [within the deviation \pm 0.019 (2) $\AA$ ] in ring $A$. The chromanone rings, $B$ and $C$, are planar [within the deviations $\pm 0.020(2)$ and \pm 0.0232 (2) $\AA$ respectively] and almost coplanar with the mean plane passing through ring $A$. The $\mathrm{O}$ atoms $[\mathrm{O}(11), \mathrm{O}(14)$ and $\mathrm{O}(15)]$ are almost in the least-squares plane passing through the three fused-ring skeleton of the molecule. The phenyl ring at $C(4)$ makes a dihedral angle of $68.4(3)^{\circ}$ with ring $C$. A strong intramolecular hydrogen bond $\mathrm{O}(15)-\mathrm{H}(15) \cdots \mathrm{O}(14)$ (Table 4) may be the cause of the slight increase in the $\mathrm{C}(8)=\mathrm{O}(14)$ length, 1.229 (3) $\AA$, compared with $\mathrm{C}(2)=\mathrm{O}(11)$, $1 \cdot 194$ (3) $\AA$. Three short intermolecular $\mathrm{C}-\mathrm{H} \cdots \mathrm{O}$ distances (Taylor \& Kennard, 1982) are listed in Table 4.

The authors acknowledge the help of the Department of Chemistry, University of Rajasthan, Jaipur, in extending the CAD- 4 facility for intensity data collection.

\section{References}

Debaerdemaeker, T., Germain, G., Main, P., RefaAt, L. S., TATE, C. \& Woolfson, M. M. (1988). MULTAN88. A System of Computer Programs for the Automatic Solution of Crystal Structures from $X$-ray Diffraction Data. Univs. of York, England, and Louvain, Belgium.

DewICK, P. M. (1982). The Flavonoid: Advances in Research, Isoflavonoids, edited by J. B. HARBORNE \& T. J. MARBY, pp. 535-640. London: Chapman \& Hall.

Main, P., Germain, G. \& Woolfson, M. M. (1984). MULTAN11/84. A System of Computer Programs for the Automatic Solution of Crystal Structures from $X$-ray Diffraction Data. Univs. of York, England, and Louvain, Belgium.

Motherwell, W. D. S. \& ClegG, W. (1978). PLUTO. Program for plotting the molecular and crystal structures. Univ. of Cambridge, England.

Murray, R. D. H., Mendez, J. \& Brown, S. A. (1982). The Natural Coumarins, Occurrence, Chemistry and Biochemistry. New York: Wiley-Interscience. 
Narkhede, D. D. (1990). PhD Thesis, Indian Institute of Technology, Bombay 400076 , India.

SHELDRICK, G. M. (1976). SHELX76. Program for crystal structure determination. Univ. of Cambridge, England.
Stout, G. H., Rickernell, G. K. \& Sears, K. D. (1968). J. Org. Chem. 33, 4191-4200.

TAylor, R. \& Kennard, O. (1982). J. Am. Chem. Soc. 104, 5063-5070.

Acta Cryst. (1991). C47, 1925-1927

\title{
Structure of a New Benzofuran Derivative
}

\author{
By Kalyan Das and U. C. Sinha* \\ Department of Physics, Indian Institute of Technology, Bombay 400 076, India \\ S. R. Desai and S. V. Bhat \\ Department of Chemistry, Indian Institute of Technology, Bombay 400 076, India
}

and S. S. Tavale and V. G. Puranik

Physical and Structural Chemistry Division, National Chemical Laboratory, Pune 411 008, India

(Received 6 December 1990; accepted 13 February 1991)

\begin{abstract}
Epoxy-7a-hydroxy-3,7,7-trimethyl2,3,3a,7a-tetrahydro-7 $\mathrm{H}$-benzofuran-4-one, $\mathrm{C}_{11} \mathrm{H}_{14^{-}}$ $\mathrm{O}_{4}$, m.p. $=408 \mathrm{~K}, M_{r}=210 \cdot 23$, monoclinic, $P 2_{1} / c$, $a=8.230(1), \quad b=10.030(1), \quad c=12.727$ (1) $\AA$, $\beta=96 \cdot 29(1)^{\circ}, \quad V=1044 \cdot 28 \AA^{3}, \quad Z=4, \quad D_{x}=$ $1.337 \mathrm{Mg} \mathrm{m}^{-3}, \lambda($ Mo $K \alpha)=0.71069 \AA, \mu($ Mo $K \alpha)$ $=0.062 \mathrm{~mm}^{-1}, F(000)=448, T=295 \mathrm{~K}$, final $R=$ $0.045, w R=0.053$ for 1437 observed reflections. Both the rings in the molecule are cis fused. Intermolecular $\mathrm{O}-\mathrm{H} \cdots \mathrm{O}$ and $\mathrm{C}-\mathrm{H} \cdots \mathrm{O}$ interactions are observed.
\end{abstract}

Introduction. The benzofuran derivative $(A)$ (Desai, Gore \& Bhat, 1990) was found to undergo autooxidation (see below), like other 2,5-dihydrofuran derivatives (Frincke, McIntyre \& Faulkner, 1980), yielding a new crystalline product $(B)$. The structure and stereochemistry of compound $(B)$ could not be assigned unambiguously on the basis of spectroscopic studies. The crystal structure of this rather unusual new product was studied using X-ray diffraction techniques in order to establish its stereochemistry in detail.

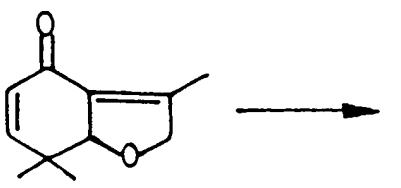

(A)



(B)

\footnotetext{
* To whom correspondence should be addressed.
}

0108-2701/91/091925-03\$03.00
Experimental. The compound was recrystallized from petroleum ether and chloroform solution as colourless crystals. A crystal of dimensions $0 \cdot 22 \times$ $0.40 \times 0.40 \mathrm{~mm}$ was used for intensity data collection with an Enraf-Nonius CAD-4 diffractometer with graphite-monochromated Mo $K \alpha \quad(\lambda=0.71069 \AA)$ radiation. The cell parameters were refined using 25 reflections in the range $11 \leq \theta \leq 18^{\circ}$. A total of 1539 reflections were scanned, $\omega / 2 \theta$ mode, in the range $0 \leq \theta \leq 23 \cdot 5^{\circ} ; 0 \leq h \leq 9,0 \leq k \leq 11,-14 \leq l \leq 14$. Three standard reflections $(356,464$ and $37 \overline{4})$ measured every $1800 \mathrm{~s}$ showed no significant intensity variation. The data were corrected for $L p$ factors and absorption effects were ignored. Equivalent reflections were merged, $R_{\text {int }}=0 \cdot 011$. Out of 1503 unique reflections, 1466 reflections with $\left|F_{o}\right| \geq$ $2 \sigma\left|F_{o}\right|$ were used for structure solution. The structure was solved by direct methods using MULTAN88 (Debaerdemaeker, Germain, Main, Refaat, Tate and Woolfson, 1988); all the non-H atoms were located from the $E$ map with the best CFOM. The refinement was by least-squares methods based on $F$ values using SHELX76 (Sheldrick, 1976). The atomic scattering factors for all the atoms were from SHELX76. The non-H atoms were refined anisotropically. All $\mathrm{H}$ atoms were located from the difference map and refined with isotropic thermal parameters. In the final refinement, 192 parameters were refined using 1437 observed reflections (with $\left|F_{o}\right| \geq 2 \cdot 5 \sigma\left|F_{o}\right|$ ). The reflections with $F_{c}>F_{o}$ and $\left|F_{o}-F_{o}\right|>4.0 \sigma\left(\left|F_{o}\right|\right)$ were omitted. Final $R=0.0452, \quad w R=0.0535$ \{where $\left.w=1.000 /\left[\sigma^{2}\left(F_{o}\right)+0.00886\left(F_{o}\right)^{2}\right]\right\}, \quad$ GOOF $=0.7923$,

(C) 1991 International Union of Crystallography 